\title{
Crustal accretion in a back-arc slow- spreading ridge: Insights from the Mado Megamullion core complex (Shikoku Basin)
}

\author{
*BASCH V. ${ }^{1}$, SANI C. ${ }^{1}$, SANFILIPPO A. ${ }^{1}$, OHARA Y. ${ }^{2,3,4}$,
} SNOW J. ${ }^{5}$, HARIGANE Y. ${ }^{6}$, YAMASHITA $\mathrm{H}^{7}$

*Correspondence: valentin.basch@gmail.com

${ }^{1}$ University of Pavia, Italy;

${ }^{2}$ Hydrographic and Oceanographic Department of Japan;

${ }^{3}$ JAMSTEC, Yokosuka, Japan;

${ }^{4}$ Nagoya University, Japan;

${ }^{5}$ Louisiana State University, USA;

${ }^{6}$ Geological Survey of Japan;

${ }^{7}$ Kanagawa Prefectural Museum of Natural History, Japan

Oceanic core complexes (OCCs) represent tectonic windows into the oceanic lower crust and mantle; as such they are key structures in understanding the tectonomagmatic processes shaping the oceanic lithosphere. We here present a first petrological and geochemical study of gabbros recently collected at the Mado Megamullion OCC, in the extinct Shikoku backarc basin (Philippine Sea).

Bathymetric surveys reveal spreading-parallel corrugations extending for $25 \mathrm{~km}$ from the breakaway to the termination, with a total extent of the corrugated surface of $\sim 550 \mathrm{~km}^{2}$. Samples were collected in several locations and include peridotites, gabbros, dolerite and rare pillow basalts. Gabbros range from granular olivine gabbros to varitextured gabbros and oxide gabbros, all widely crosscut by felsic veins. These gabbroic rocks reveal a complex tectonomagmatic evolution that includes: $i$ ) emplacement within the lithospheric mantle (from olivine gabbros to oxide gabbros); ii) dynamic recrystallization under granulite- to amphibolitefacies conditions $\left(700-850^{\circ} \mathrm{C}\right)$; iii) multistage intrusion of highly evolved melts forming felsic segregations with sharp to diffuse contacts with the host rock. This event locally led to the formation of hybridized gabbro, defined by the occurrence of amphibole $+\mathrm{Ti}-\mathrm{Fe}$ oxides + apatite reaction coronas around primary clinopyroxene crystals; $i v)$ exposure on the seafloor and low-temperature alteration. Overall, this metamorphic evolution recalls that of the lower crust from other OCCs oceanwide, thus demonstrating that the gabbros of the Mado Megamullion represent deep-seated intrusions progressively exhumed by detachment faulting.

Mineral major and trace element compositions suggest that the melts forming the gabbros was generated at low degrees of partial melting of a DMM-like asthenosphere, consistent with their emplacement during the progressive extinction of the Shikoku Basin backarc spreading ridge. 